\begin{tabular}{l|l} 
Jurnal Eksplorasi Akuntansi & $\begin{array}{l}\text { ISSN : 2656-3649 (Online) } \\
\text { hol. 2, No 2, Seri A, Mei 2020, Hal 2638-2658:/jea.ppj.unp.ac.id/index.php/jea/issue/view/22 }\end{array}$
\end{tabular}

\title{
PENGARUH BIOLOGICAL ASSET INTENSITY, GROWTH, LEVERAGE, DAN TINGKAT INTERNASIONAL TERHADAP PENGUNGKAPAN ASET BIOLOGIS
}

(Studi pada Perusahaan Agrikultur yang Terdaftar di BEI Tahun 2015-2018)

\author{
Kurnia Hayati ${ }^{1}$, Vanica Serly ${ }^{2}$ \\ ${ }^{1}$ Alumni Jurusan Akuntansi Fakultas Ekonomi Universitas Negeri Padang \\ 2Jurusan Akuntansi Fakultas Ekonomi Universitas Negeri Padang \\ *Korespondensi: kurniahayati1306@gmail.com
}

\begin{abstract}
Data from the Central Statistics Agency shows Indonesia's agricultural growth rate in the first quarter of 2019 was only 1.81\%. This growth rate decreased significantly, when compared to the first quarter of 2018 which reached 3,34\%. This indicates that the condition of agriculture in Indonesia is very alarming. This study aims to see the effect of biological asset intensity, growth, leverage and international level to biological asset disclosure in agricultural companies listed on the Indonesia Stock Exchange (IDX) for the period 2015-2018. Disclosure of biological asset in this study refers to PSAK 69 with 36 items of disclosure. This type of research is quantitative. The population in this study were all agricultural companies listed on the Indonesia Stock Exchange (IDX), with a total sample of 66 samples using a purposive sampling method. The analysis was done by using multiple regression model. The results of this study indicate that: (1) The biological asset intesity has a positive and significant effect on the disclosure of biological asset, (2) Growth has a positive and significant effect on the disclosure of biological asset, (3) Leverage has a negative and not significant effect on the disclosure of biological asset, (4) The international level has a negative and not significant effect on the disclosure of biological asset
\end{abstract}

Keywords: Biological Asset Disclosure; Biological Asset Itensity; Growth; International Level; Leverage

How to cite (APA $6^{\text {th }}$ style):

Hayati, K., \& Serly, V. (2020). Pengaruh Biological Asset Intensity, Growth, Leverage, dan Tingkat Internasional Terhadap Pengungkapan Aset Biologis (Studi pada Perusahaan Agrikultur yang Terdaftar di BEI Tahun 2015-2018). Jurnal Eksplorasi Akuntansi. 2(2), Seri A, 2638-2658.

\section{PENDAHULUAN}

Indonesia merupakan negara kepulauan terbesar di dunia, memiliki luas wilayah sebesar $5.455 .675 \mathrm{~km}^{2}$ dan $3.544 .744 \mathrm{~km}^{2}$ merupakan lautan, menjadikan Indonesia sebagai negara yang kaya akan sumber daya alamnya. Iklim tropis dan curah hujan yang tinggi menyebabkan tanah di Indonesia dapat ditanami oleh berbagai jenis tanaman dan mampu memberikan hasil yang 
melimpah. Potensi sumber daya alam yang besar tersebut, seharusnya dapat memenuhi kebutuhan pangan bangsanya dan mengurangi kegiatan impor hasil pertanian.

Faktanya, kondisi pertanian di Indonesia saat ini sangat memprihatinkan. Indonesia menjadi negara pengimpor buah-buahan, ternak, dan bahan pangan utama seperti beras, jagung, dan gula. Padahal, di tahun 1980-an Indonesia merupakan negara pengekspor utama beras (F. Amelia, 2017). Badan Pusat Statistik (BPS) juga menyajikan data yang menunjukkan angka pertumbuhan pertanian di Indonesia pada kuartal pertama tahun 2019 hanya mencapai 1,81\%. Angka pertumbuhan ini menurun secara signifikan jika dibandingkan dengan kuartal yang sama pada tahun 2018 yaitu sebesar 3,34\%. Angka ini juga merupakan pertumbuhan Produk Domestik Bruto (PDB) sektor pertanian yang paling rendah setidaknya sejak kuartal pertama tahun 2017.

Sektor agrikultur harus terus dikembangkan karena menjadi salah satu tulang punggung dalam pembangunan perekonomian nasional di Indonesia (Yurniwati et al., 2018). Pengembangan pada sektor agrikultur didukung oleh ketersediaan informasi yang memadai (Sa'diyah et al., 2019). Infomasi tersebut disajikan dalam bentuk laporan keuangan yang akan digunakan oleh pihak internal dan eksternal dalam proses pengambilan keputusan. Agar informasi dalam laporan keuangan dapat dipahami dan tidak salah diinterpretasikan oleh pengguna laporan keuangan, maka penyajiannya harus disertai dengan pengungkapan.

Pengungkapan yang dilakukan oleh perusahaan agrikultur sedikit berbeda dengan industri lainnya, karena perusahaan agrikultur memiliki aset utama berupa aset biologis (Sari, 2019). Aset biologis menurut Pernyataan Standar Akuntansi Keuangan (PSAK) 69 Agrikultur adalah tanaman atau hewan hidup. Aset ini dapat mengalami transformasi biologis yang dimulai dari proses pertumbuhan, degenerasi, prokreasi, dan produksi sehingga menyebabkan perubahan kualitatif dan kuantitatif pada tanaman atau hewan hidup tersebut (Alfiani, 2019). Perbedaan inilah yang mengharuskan perusahaan agrikultur untuk melakukan pengungkapan mengenai aset biologis yang dimilikinya. Pengungkapan aset biologis tersebut akan berguna untuk menginformasikan nilai aset biologis yang wajar sesuai dengan kontribusinya, dalam menghasilkan aliran manfaat ekonomis bagi perusahaan kepada pemangku kepentingan (Kusumadewi, 2018).

Pengungkapan aset biologis yang dilakukan oleh perusahaan agrikultur akan meningkat seiring dengan peningkatan yang terjadi pada intensitas aset biologisnya (Duwu, 2018). Menurut Alfiani (2019) intensitas aset biologis (biological asset intensity) adalah gambaran seberapa besar proporsi investasi perusahaan terhadap aset biologis perusahaan. Biological asset intensity juga dapat menggambarkan ekspektasi kas yang diterima jika aset tersebut dijual (Gonçalves \& Lopes, 2014). Menurut Putri \& Siregar (2019) jika sebuah perusahaan memiliki nilai aset biologis yang tinggi, maka perusahaan tersebut akan mengungkapkannya dalam catatan atas laporan keuangan.

Penelitian Goncalves \& Lopes (2014) mengenai praktek pengungkapan akuntansi perusahaan agrikultur di bawah International Accounting Standar (IAS) 41 Agriculture menunjukkan, bahwa tingkat pengungkapan aset biologis akan lebih intensif pada perusahaan yang memiliki biological asset intensity yang lebih besar. Hasil penelitian tersebut didukung oleh Selahudin et al (2018) yang meneliti pada perusahaan agrikultur di Malaysia. Biological asset intensity yang tinggi menyebabkan perusahaan akan meningkatkan pengungkapan aset biologisnya untuk menginformasikan kepada para stakeholder mengenai proporsi investasi perusahaan terhadap aset biologis. Penelitian Yurniwati, et al (2018) pada perusahaan agrikultur di Indonesia menujukkan hal yang serupa, bahwa biological aset intensity berpengaruh positif terhadap pengungkapan aset biologis. Namun, bertolak belakang dengan penelitian yang 
dilakukan oleh Pramitasari (2018) dan Sa'diyah, et al (2019) menyatakan bahwa biological asset intensity berpengaruh negatif terhadap pengungkapan aset biologis. Tingginya biological asset intensity yang dimiliki oleh perusahaan agrikultur tidak menjamin keluasan pada pengungkapan yang dilakukan. Perusahaan dengan proporsi aset biologis yang rendah justru mengungkapkan lebih banyak informasi mengenai aset biologis yang dimilikinya.

Pertumbuhan perusahaan (growth) pada sektor agrikultur merupakan kemampuan yang dimiliki oleh perusahaan agrikultur untuk meningkatkan aset perusahaan (Alfiani, 2019). Growth dapat digunakan sebagai bahan penilaian bagi investor dalam berinvestasi pada perusahaan. Investor cenderung lebih memilih berinvestasi pada perusahaan yang memiliki peluang lebih besar dalam potential growth, dengan demikian mereka akan menambah modal atau dana untuk perusahaan agar dapat meningkatkan produktivitas bisnisnya (Daniel et al., 2010). Oleh sebab itu, perusahaan yang memiliki tingkat pertumbuhan yang tinggi akan cenderung lebih banyak mendapatkan sorotan, sehingga perusahaan tersebut akan melakukan pengungkapan yang lebih luas mengenai aset biologisnya.

Penelitian yang dilakukan oleh Alfiani (2019) pada perusahaan agrikultur di Indonesia menunjukkan hasil, bahwa peningkatan pengungkapan aset biologis meningkat sejalan dengan pertumbuhan yang terjadi pada perusahaan. Perusahaan dengan pertumbuhan yang tinggi akan lebih banyak melakukan pengungkapan untuk dapat mengurangi biaya politis mereka (D. Amelia, 2016). Pernyataan tersebut juga didukung dengan penelitian yang dilakukan oleh Munsaidah, et al (2016) bahwa perusahaan dengan pertumbuhan yang tinggi akan melakukan pengungkapan yang lebih luas. Bertolak belakang dengan hasil penelitian sebelumnya, Lopes \& Goncalves (2015) dan Selahudin, et al (2018) menemukan bahwa growth berpengaruh negatif terhadap pengungkapan aset biologis. Perusahaan dengan pertumbuhan yang tinggi akan cenderung mengungkapkan lebih sedikit informasi mengenai aset biologis yang dimiliki. Sebaliknya, perusahaan dengan tingkat pertumbuhan yang rendah akan melakukan pengungkapan yang lebih lengkap dan rinci mengenai aset biologisnya.

Perusahaan agrikultur dalam memperoleh dana dapat bersumber dari kreditor dan pemegang saham. Leverage akan menunjukkan seberapa besar tingkat ketergantungan perusahaan kepada kreditor dibandingkan dengan pemegang sahamnya dalam membiayai aset perusahaan (Purnasiwi, 2011). Menurut Brigham \& Houston (2013) kreditor lebih menyukai perusahaan dengan tingkat rasio utang yang rendah, karena semakin rendah rasio utang perusahaan maka makin besar perlindungan terhadap kerugian yang ditanggung kreditor jika terjadi likuidasi. Disisi lain, pemegang saham justru lebih menginginkan leverage yang tinggi karena dapat meningkatkan produktivitas perusahaan sehingga laba yang dihasilkan perusahaan pun semakin besar.

Rasio laverage yang tinggi dapat mendorong perusahaan dalam menyampaikan lebih banyak informasi untuk memenuhi kebutuhan para pemangku kepentingan serta mengurangi biaya agensi (Putri, 2017). Tambahan informasi perusahaan berguna untuk menghilangkan keraguan para pemegang obligasi terhadap dipenuhinya hak-hak mereka sebagai kreditor. Penelitian yang dilakukan oleh Machdar (2014), menemukan bahwa perusahaan yang memiliki tingkat leverage yang tinggi akan melakukan pengungkapan yang semakin luas. Penelitian yang dilakukan oleh Selahudin et al (2018) juga menemukan hal yang sama, bahwa leverage berpengaruh positif terhadap pengungkapan aset biologis pada perusahaan agrikultur di Malaysia.

Hasil penelitian Lopes \& Goncalves (2015) bertolak belakang dengan para peneliti sebelumnya. Perusahaan agrikultur dengan leverage yang tinggi akan melakukan pengungkapan yang lebih sedikit jika dibandingkan perusahaan agrikultur dengan leverage yang rendah. Hal 
tersebut berkaitan dengan respon yang akan diberikan kreditor kepada perusahaan. Pengungkapan aset biologis secara luas membuat kreditor akan beranggapan bahwa banyaknya aset biologis yang dimiliki oleh perusahaan dibiayai oleh hutang, sehingga menjadi sinyal negatif bagi kreditor.

Perusahaan agrikutur di Indonesia sudah berada pada tahap internasional dibuktikan dengan adanya Masyarakat Ekonomi ASEAN (MEA) pada akhir tahun 2015. Tingkat internasionalisasi berkaitan dengan tingkat aktivitas asing di perusahaan (Daske et al., 2013). Perusahaan yang telah berada pada posisi internasional dituntut untuk meningkatkan pengungkapan informasi keuangannya, mengingat bahwa perusahaan yang besar dengan tingkat kompleksitas aktivitas yang tinggi pasti memiliki stakeholders yang lebih banyak (Sa'diyah et al., 2019). Penelitian Souza \& Almeida (2017) pada perusahaan di Brazil menemukan, bahwa perusahaan dengan tingkat internasional yang tinggi akan melakukan pengungkapan yang lebih luas pada laporan keuangannya. Hasil penelitian tersebut di dukung oleh Pramitasari (2018) yang menguji pada perusahaan agrikultur di Indonesia, memperoleh hasil bahwa tingkat internasional berpengaruh positif terhadap pengungkapan aset biologis. Semakin tinggi tingkat internasionalisasi pada perusahaan agrikultur maka semakin luas pula dalam mengungkapan aset biologisnya. Penelitian Lopes \& Goncalves (2015) memberikan hasil yang bertolak belakang dari hasil penelitian sebelumnya, bahwa tingkat internasional berpengaruh negatif terhadap pengungkapan aset biologis. Hasil yang sama di dapatkan oleh Sa'diyah et al (2019) yang meneliti pada perusahaan agrikultur di Indonesia. Perusahaan dengan tingkat internasionalisasinya yang rendah cenderung melakukan pengungkapan aset biologis lebih lengkap, jika dibandingkan pada perusahaan agrikultur yang mempunyai tingkat internasional yang tinggi.

Hasil yang berbeda dari beberapa peneliti sebelumnya serta fenomena yang terjadi di Indonesia, membuat penulis tertarik untuk melakukan penelitian kembali. Penelitian ini akan mengacu pada penelitian yang telah dilakukan oleh Yurniwati et al (2018). Perbedaan dari penelitian sebelumnya ialah: pertama, terletak dari periode penelitian yang dilakukan. Penelitian ini menggunakan periode 2015-2018 sedangkan penelitian sebelumnya pada periode 2012-2015. Kedua, peneliti menggunakan variabel baru yaitu growth, leverage dan tingkat internasional. Ketiga, dalam penelitian ini peneliti menggunakan item pengungkapan aset biologis berdasarkan PSAK 69 Agrikultur, sedangkan pada penelitian sebelumnya menggunakan item pengungkapan aset biologis berdasarkan IAS 41 Agriculture.

\section{REVIU LITERATUR DAN HIPOTESIS}

\section{Teori Agency}

Teori agency menurut Jensen \& Meckling (1976) ialah teori yang menjelaskan hubungan kontraktual antara principal dan agent. Hubungan kontraktual tersebut akan memunculkan agency problem yang disebabkan oleh perbedaan kepentingan antara agent dan principal. Meskipun, principal adalah pihak yang memberikan wewenang kepada agent namun principal tidak dapat mengawasi kinerja agent setiap saat (Yamaditya \& Raharja, 2014). Manajer sebagai agent dapat bertindak sesuai dengan kepentingannya sendiri dan mengabaikan kepentingan para pemegang saham atau principal dengan cara memaksimalkan keuntungan pribadi. Hal tersebut disebabkan adanya asimetri informasi antara agent selaku pihak yang menyediakan informasi dengan principal sebagai pengguna informasi.

Asimetri informasi terjadi karena principal memiliki informasi yang lebih sedikit jika dibandingkan dengan agent. Sebaliknya, agent sebagai pengelola perusahaan lebih mengetahui 
informasi secara lengkap mengenai perusahaan (Yamaditya \& Raharja, 2014). Asimetri informasi dapat diatasi jika manajemen menyajikan informasi yang sesuai dengan keadaan sesungguhnya. Agar informasi tersebut dapat berguna bagi investor, maka diperlukan pengungkapan pada laporan keuangan (Kamijaya, 2019). Pengungkapan yang secara luas akan memberikan kemudahan bagi para pemakai laporan keuangan untuk memahami serta membandingkan informasi yang disajikan, sehingga mengurangi asimetri yang terjadi.

\section{Teori Stakeholder}

Teori stakeholder ialah teori yang menyatakan bahwa perusahaan harus memberikan manfaat kepada stakeholder, bukan hanya beroperasi untuk kepentingannya sendiri (Ghozali \& Chariri, 2007). Teori stakeholder menurut Deegan (2004), menjelaskan bahwa semua stakeholder berhak untuk mengetahui setiap informasi dari kegiatan organisasi yang dapat mempengaruhi kedudukan mereka. Stakeholder tersebut terdiri dari para pemegang saham, kreditor, customer, supplier, pemerintah, masyarakat, analis dan pihak lainnya. Mereka memiliki kepentingan serta peran yang berbeda-beda mengenai organisasi dalam melaksanakan operasinya. Walaupun demikian, kelangsungan hidup sebuah perusahaan bergantung kepada dukungan yang diberikan oleh semua stakeholder yang ada.

Manajemen perusahaan akan berusaha untuk mendapatkan dukungan serta kepercayaan setiap stakeholder-nya, dengan cara menyediakan informasi yang dibutuhkan oleh para stakeholder (Alfiani, 2019). Menurut F. Amelia (2017) agar informasi yang disajikan dapat dipahami dan tidak salah diinterpretasikan, maka harus disertai dengan pengungkapan pada laporan tahunannya (annual report). Pengungkapan yang secara luas akan membuat perusahaan mudah menarik investor dan meyakinkan kreditor untuk meningkatkan pendanaan mereka pada perusahaan.

\section{Teori Signaling}

Teori signaling menurut Astuti (2015) mengemukakan tentang bagaimana perusahaan memberikan sinyal kepada pengguna laporan keuangan. Sinyal tersebut berisi informasi mengenai apa saja yang telah dilakukan oleh pihak manajemen perusahaan dalam merealisasikan keinginan pemilik. Menurut Gumanti (2009) setiap informasi yang dikeluarkan oleh perusahaan bisa merubah penilaian investor ataupun kreditor terhadap perusahaan, karena dapat menjadi sinyal postif maupun sinyal negatif bagi mereka.

Manajemen akan berusaha untuk mengungkapan informasi privat perusahaan yang menurut pertimbangannya sangat diminati oleh investor, jika informasi tersebut dapat menjadi berita baik (good news) dan mejadi sinyal positif terhadap perusahaan. Hal tersebut dilakukan agar pihak eksternal tidak memberikan harga yang rendah untuk perusahaan sebagai bentuk perlindungan diri mereka dari asimetri informasi yang terjadi (Gumanti, 2009). Sehingga, manajemen perusahaan akan selalu hati-hati dalam memilah informasi yang akan diungkapkannya secara rinci dalam laporan tahunan (annual report) perusahaan.

\section{Pengungkapan}

Pengungkapan secara konseptual ialah bagian dari pelaporan keuangan, namun secara teknis merupakan langkah akhir dalam proses akuntansi yaitu menyajikan informasi dalam bentuk seperangkat penuh statement keuangan (Suwardjono, 2014). Pengungkapan tersebut menyajikan informasi yang diperlukan agar mencapai tujuan pelaporan keuangan dan untuk melayani berbagai pihak yang mempunyai kepentingan yang berbeda-beda. Menurut F. Amelia (2017) 
perusahaan akan melakukan pengungkapan melebihi dari apa yang diwajibkan jika mereka merasa pengungkapan tersebut akan menurunkan biaya modalnya atau mereka tidak ingin ketinggalan praktik-praktik pengungkapan yang kompetitif. Sebaliknya, perusahaan akan mengungkapkan lebih sedikit informasi jika mereka merasa pengungkapan tersebut akan memperlihatkan rahasia kepada pesaing atau memperlihatkan sisi buruknya

\section{Aset Biologis}

Aset biologis menurut PSAK 69 Agrikultur adalah aset berupa hewan atau tanaman hidup seperti, domba, sapi perah, tanaman kapas, tebu, tanaman tembakau dan lain sebagainya. Aset biologis ini memiliki kerakteristik yang berbeda dengan aset lainnya karena mengalami transformasi biologis. Transformasi biologis tersebut terdiri dari proses pertumbuhan, degenerasi, prokreasi atau produksi produk pertanian (Kusumadewi, 2018). Menurut PSAK 69 Agrikultur perusahaan sektor agrikultur dapat mengklasifikasikan aset biologis yang dimilikinya, sebagai aset biologis yang dapat dikonsumsi dan aset biologis produktif atau sebagai aset biologis yang menghasilkan dan aset biologis yang belum menghasilkan. Aset biologis yang dapat dikomsumsi adalah aset yang dipanen sebagai produk agrikultur atau dijual sebagai aset biologis, seperti hewan ternak untuk dijual dan pohon yang ditanam untuk menghasilkan kayu. Sebaliknya, aset biologis produktif ialah aset biologis yang tidak termasuk produk agrikultur namun dimiliki untuk menghasilkan produk agrikulturnya seperti, hewan ternak yang digunakan untuk menghasilkan susu dan tanaman yang diambil buahnya.

\section{Pengungkapan Aset Biologis}

Pengungkapan aset biologis adalah pengungkapan yang dilakukan oleh perusahaan agrikultur mengenai aktivitas manajemen yang dilakukannya seperti, mengubah atau mengolah aset biologis (Alfiani, 2019). Pengungkapan aset biologis berguna untuk menginformasikan nilai aset biologis yang wajar sesuai dengan kontribusinya, dalam menghasilkan aliran manfaat ekonomis bagi perusahaan kepada semua pemangku kepentingan (Kusumadewi, 2018). Berdasarkan PSAK 69 Agrikultur setiap entitas dianjurkan untuk memberikan penjelasan naratif dan kuantitatif mengenai setiap kelompok aset biologis yang dimilikinya. Hal tersebut, berguna untuk membedakan antara aset biologis yang dapat dikonsumsi dan aset biologis produktif atau aset biologis yang menghasilkan (mature) dan aset biologis yang belum menghasilkan (immature).

\section{Biological Asset Intensity}

Biological asset intensity atau intensitas aset biologis adalah proporsi investasi perusahaan agrikultur terhadap aset biologis yang dimilikinya (Duwu, 2018). Biological asset intensity juga dapat menggambarkan ekspektasi kas yang diterima jika aset tersebut dijual (Goncalves \& Lopes, 2014). Perusahaan agrikultur yang aset utamanya adalah aset biologis wajib melakukan pengungkapan aset biologis. Informasi mengenai aset biologis akan berguna bagi stakeholder untuk mengetahui seberapa besar proporsi investasi perusahaan terhadap aset biologis yang ada di dalam perusahaan tersebut.

\section{Growth}

Growth menurut Harahap (2013) adalah rasio pertumbuhan yang menggambarkan persentase pertumbuhan pos-pos perusahaan dari tahun ke tahun. Menurut Alfiani (2019), pertumbuhan terhadap aset yang digunakan dalam kegiatan operasional perusahaan agrikultur dapat 
menggambarkan kemampuan perusahaan untuk meningkatkan perluasan pada usahanya. Perusahaan akan melakukan pengungkapan aset biologis di laporan tahunannya untuk menginformasikan kepada stakeholder pertumbuhan yang terjadi pada perusahaan.

\section{Leverage}

Leverage merupakan rasio yang menggambarkan hubungan antara hutang perusahaan terhadap modal (Harahap, 2013). Rasio laverage yang tinggi dapat mendorong perusahaan dalam menyampaikan lebih banyak informasi untuk memenuhi kebutuhan para pemangku kepentingan serta mengurangi biaya agensi (Putri, 2017). Pengungkapan aset biologis yang dilakukan perusahaan agrikultur akan memberikan informasi mengenai nilai aset biologis yang wajar sesuai dengan kontribusinya dalam menghasilkan aliran kas bagi perusahaan. Informasi tersebut berguna untuk menghilangkan keraguan para pemegang obligasi terhadap dipenuhinya hak-hak mereka sebagai kreditor.

\section{Tingkat Internasional}

Tingkat Internasionalisasi berkaitan dengan tingkat aktivitas asing di perusahaan (Daske et al., 2013). Menurut Diphayana (2014) perusahaan internasional merupakan perusahaan yang mulai mengembangkan kegiatan bisnisnya ke luar negeri termasuk kegiatan pemasaran, pengembangan pabrik dan kegiatan lainnya, namun masih berorientasi di dalam negeri. Perusahaan yang telah berada pada posisi internasional akan dituntut untuk meningkatkan pengungkapan informasi keuangannya, mengingat bahwa perusahaan yang besar dengan tingkat kompleksitas aktivitas yang tinggi pasti memiliki stakeholders yang lebih banyak (Sa'diyah et al., 2019). Pengungkapan secara luas mengenai aset biologis pada perusahaan agrikultur akan membuat laporan keuangan memiliki kualitas yang lebih tinggi dan mempermudah investor serta para pemakai laporan keuangan lainnya untuk memahami dan membandingkan informasi yang ada.

\section{Pengaruh Biological Asset Intensity Terhadap Pengungkapan Aset Biologis}

Teori stakeholder menyatakan bahwa perusahaan harus memberikan manfaat kepada stakeholder bukan hanya beroperasi untuk kepentingannya sendiri (Ghozali \& Chariri, 2007). Manajemen perusahaan akan berusaha untuk mendapatkan dukungan serta kepercayaan setiap stakeholdernya, dengan cara menyediakan informasi yang dibutuhkan oleh para stakeholder (Alfiani, 2019). Adanya informasi mengenai biological asset intensity akan memudahkan stakeholder untuk mengetahui seberapa besar proporsi investasi perusahaan terhadap aset biologis yang dimiliki. Hal tersebut di dukung oleh hasil penelitian Goncalves \& Lopes (2014) yang menemukan bahwa, biological asset intensity berpengaruh positif signifikan terhadap pengungkapan aset biologis yang diukur dengan menggunakan rasio aset biologis dibagi total aset.

Hasil penelitian Selahudin, et al (2018) menunjukkan adanya pengaruh positif signifikan antara biological asset intensity terhadap pengungkapan aset biologis pada perusahaan agrikultur di Malaysia. Penelitian yang serupa juga dilakukan oleh Yurniwati, et al (2018), Duwu (2018) dan Putri \& Siregar (2019) pada perusahaan agrikultur di Indonesia. Temuan penelitiannya adalah biological assets intensity berpengaruh positif signifikan terhadap pengungkapan aset biologis. Dari hasil penelitian yang telah dilakukan oleh beberapa peneliti sebelumnya, maka penulis berpendapat bahwa semakin tinggi biological assets intensity yang dimiliki oleh perusahaan agrikultur, maka semakin banyak pula pengungkapan yang harus dilakukan perusahaan agrikultur mengenai aset biologisnya. Hipotesis yang dirumuskan dalam penelitian ini adalah sebagai berikut: 
$\mathbf{H}_{\mathbf{1}}$ : Biological asset intensity berpengaruh positif terhadap pengungkapan aset biologis.

\section{Pengaruh Growth Terhadap Pengungkapan Aset Biologis}

Teori stakeholder menjelaskan bahwa semua stakeholder berhak untuk mengetahui setiap informasi dari kegiatan organisasi yang dapat mempengaruhi kedudukan mereka (Deegan, 2004). Perusahaan yang memiliki tingkat pertumbuhan tinggi akan cenderung lebih banyak mendapatkan sorotan, sehingga perusahaan tersebut akan melakukan pengungkapan yang lebih luas mengenai informasi keuangan maupun non keuangan yang mereka miliki. Hal ini di dukung oleh hasil penelitian yang dilakukan oleh D. Amelia (2016) yang menunjukkan bahwa perusahaan dengan pertumbuhan yang tinggi akan lebih banyak melakukan pengungkapan untuk mengurangi biaya politis perusahaan. Hasil penelitian tersebut sejalan dengan penelitian yang dilakukan oleh Munsaidah, et al (2016), menemukan bahwa perusahaan dengan pertumbuhan yang tinggi akan melakukan pengungkapan yang lebih luas.

Perusahaan agrikultur mempunyai aset biologis sebagai aset utamanya. Informasi mengenai aset biologis akan berguna bagi stakeholder untuk mengetahui nilai aset biologis yang wajar sesuai dengan kontribusinya dalam menghasilkan aliran kas bagi perusahaan. Maka, pertumbuhan perusahaan pada sektor agrikultur merupakan kemampuan yang dimiliki oleh perusahaan untuk meningkatkan asetnya. Agar informasi yang disajikan dapat dipahami dan tidak salah diinterpretasikan, maka harus disertai dengan pengungkapan pada laporan tahunannya (F. Amelia, 2017). Penelitian yang dilakukan oleh Alfiani (2019) pada perusahaan agrikultur di Indonesia, menunjukkan bahwa adanya pengaruh positif pertumbuhan perusahaan terhadap pengungkapan aset biologis. Dari hasil penelitian yang telah dilakukan sebelumnya, maka penulis berpendapat bahwa semakin tinggi pertumbuhan perusahaan maka semakin luas pengungkapan yang dilakukan oleh perusahaan tersebut. Hipotesis yang dirumuskan dalam penelitian ini adalah sebagai berikut:

$\mathbf{H}_{2}$ : Growth berpengaruh positif terhadap pengungkapan aset biologis.

\section{Pengaruh Leverage Terhadap Pengungkapan Aset Biologis.}

Teori keagenan menjelaskan hubungan kontraktual antara principal dan agent (Jensen \& Meckling, 1976). Kontrak tersebut dapat terjadi antara pemegang saham dengan manajer ataupun kreditor dengan manajer perusahaan. Leverage akan mencerminkan seberapa besar suatu perusahaan bergantung kepada kreditor dalam membiayai aset perusahaan (Purnasiwi, 2011). Rasio laverage yang tinggi akan mendorong perusahaan dalam menyampaikan lebih banyak informasi untuk memenuhi kebutuhan para pemangku kepentingan serta mengurangi biaya agensi (Putri, 2017). Menurut Khanna, et al (2004) perusahaan dengan rasio utang yang tinggi harus mempunyai derajat transparansi yang tinggi, karena kreditor menuntut informasi yang lebih banyak untuk dapat menjamin dana mereka. Hal tersebut di dukung oleh hasil penelitian yang dilakukan Sinurat \& Sembiring (2016), bahwa leverage berpengaruh positif terhadap pengungkapan laporan keuangan.

Penelitian yang dilakukan oleh Selahudin, et al (2018) mengenai faktor penentu pengungkapan aset biologis pada perusahaan agrikultur di Malaysia. Hasil penelitian menunjukkan bahwa perusahaan dengan leverage yang tinggi akan lebih intensif untuk mengungkapkan informasi yang dimiliki sehingga mengurangi biaya agensi mereka. Selain itu, dengan mengungkapan lebih banyak informasi perusahaan akan meyakinkan kreditor bahwa 
lebih kecil kemungkinan bagi mereka untuk melewati klaim perjanjian pembayaran hutang. Hasil penelitian yang serupa juga di dapatkan oleh Pramitasari (2018) bahwa leverage berpengaruh postif. Dari hasil penelitian yang telah dilakukan sebelumnya, maka penulis berpendapat bahwa semakin tinggi leverage perusahaan agrikultur maka semakin banyak pula pengungkapan yang harus dilakukan perusahaan agrikultur mengenai aset biologisnya. Hipotesis yang dirumuskan dalam penelitian ini adalah sebagai berikut:

$\mathbf{H}_{3}$ : Leverage berpengaruh positif terhadap pengungkapan aset biologis.

\section{Pengaruh Tingkat Internasional Terhadap Pengungkapan Aset Biologis.}

Teori keagenan dari Jensen \& Meckling (1976) menyatakan bahwa adanya hubungan kontraktual antara principal dan agent. Manajer sebagai agent yang mengelola perusahaan lebih mengetahui keadaan perusahaan jika dibandingkan dengan principal. Sehingga, perusahaan yang telah berada pada posisi internasional dituntut untuk meningkatkan pengungkapan informasi keuangannya, mengingat bahwa perusahaan yang besar dengan tingkat kompleksitas aktivitas yang tinggi pasti memiliki stakeholders yang lebih banyak (Sa'diyah et al., 2019). Hal tersebut didukung oleh hasil penelitian yang dilakukan oleh Lestari (2016) tentang faktor-faktor yang mempengaruhi tingkat pengungkapan Internet Financial Reporting (IFR) yang memperoleh hasil, bahwa internasionalisasi berpengaruh positif terhadap pengungkapan sukarela melalui internet.

Penelitian Souza \& Almeida (2017) mengenai faktor-faktor yang berhubungan dengan tingkat pengungkapan pada semua perusahaan di Brazil tahun 2015 menemukan bahwa, tingkat internasional berpengaruh positif terhadap tingkat pengungkapan. Perusahaan dengan tingkat internasional yang tinggi akan melakukan pengungkapan yang lebih luas pada laporan keuangannya. Hal tesebut bertujuan untuk menarik investor luar supaya mau menanamkan modalnya kepada perusahaan. Penelitian yang dilakukan oleh Pramitasari (2018) pada perusahaan perkebunan di Indonesia menunjukkan bahwa tingkat internasional berpengaruh positif terhadap pengungkapan aset biologis. Dari hasil penelitian yang telah dilakukan sebelumnya, maka penulis berpendapat bahwa semakin tinggi tingkat internasional yang dimiliki oleh perusahaan agrikultur maka semakin banyak pula pengungkapan yang harus dilakukan perusahaan agrikultur mengenai aset biologisnya. Hipotesis yang dirumuskan dalam penelitian ini adalah sebagai berikut:

$\mathbf{H}_{4}$ : Tingkat internasional berpengaruh positif terhadap pengungkapan aset biologis.

\section{Kerangka Konseptual}

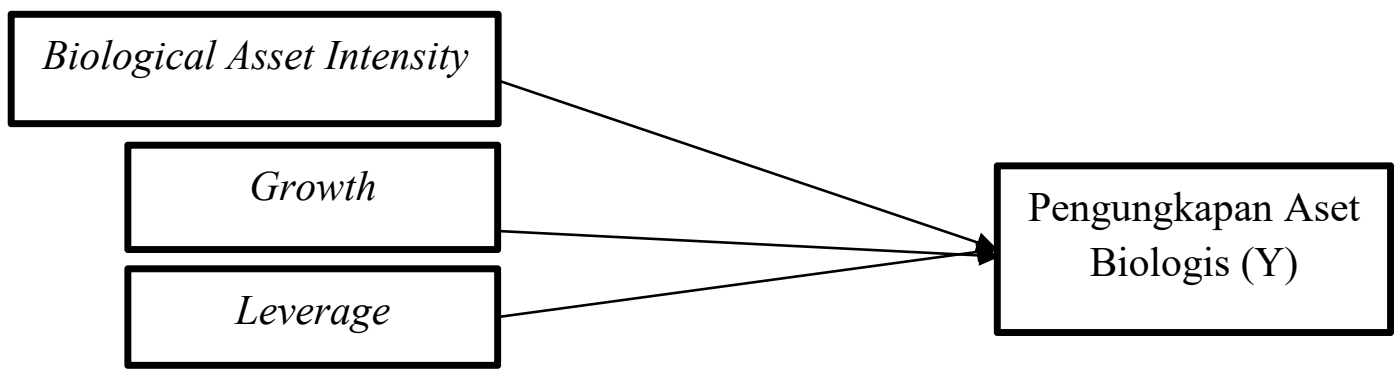

Gambar 1. Kerangka Konseptual 


\section{METODE PENELITIAN}

\section{Jenis, Populasi dan Sampel Penelitian}

Jenis penelitian yang digunakan adalah penelitian kuantitatif. Populasi yang digunakan dalam penelitian ini adalah perusahaan agrikultur yang terdaftar di Bursa Efek Indonesia (BEI). Metode yang digunakan dalam menentukan sampel ialah menggunakan metode purposive sampling. Kriteria-kriteria yang ditentukan peneliti dalam pengambilan sampel yaitu sebagai berikut

Tabel 1

Kriteria Pemilihan Sampel

\begin{tabular}{clc}
\hline No & \multicolumn{1}{c}{ Keterangan } & Jumlah \\
\hline 1. & $\begin{array}{l}\text { Perusahaan agrikultur yang terdaftar di Bursa Efek Indonesia } \\
\text { (BEI) periode 2015-2018 }\end{array}$ & 83 \\
2. & $\begin{array}{l}\text { Perusahan agrikultur yang tidak menerbitkan laporan keuangan } \\
\text { tahunan (annual report) secara lengkap pada periode 2015-2018 }\end{array}$ & (13) \\
3. & $\begin{array}{l}\text { Laporan keuangan perusahaan agrikultur yang tidak disajikan } \\
\text { dalam mata uang rupiah (Rp) }\end{array}$ & $(4)$ \\
& Total sampel perusahaan agrikultur per tahun (2015-2018) & 66 \\
\hline
\end{tabular}

Sumber: Hasil Olah Data 2020

\section{Jenis, Sumber dan Metode Pengumpulan Data}

Penelitian ini menggunakan data sekunder berupa data kuantitatif dari laporan keuangan tahunan (annual report) perusahaan agrikultur periode 2015-2018. Sumber data sekunder yang digunakan diperoleh dari situs resmi Bursa Efek Indonesia (BEI) yaitu www.idx.co.id. Metode pengumpulan data menggunakan metode dokumenter.

\section{Variabel Penelitian dan Pengukuran}

Variabel independen pada penelitian ini adalah biological asset intensity, growth, leverage dan tingkat internasional. Biological asset intensity pada penelitian ini diukur dengan cara menghitung rasio antara aset biologis dengan total aset yang dimiliki oleh perusahaan agrikultur. Growth diukur dengan melihat pertumbuhan yang terjadi pada aset perusahaan dari tahun ke tahun. Leverage diukur dengan melakukan perbandingan antara total kewajiban dibagi dengan total ekuitas pemegang saham umum (shareholder's equity). Pengukuran yang digunakan untuk menghitung tingkat internasional adalah dengan cara melakukan perbandingan antara penjualan asing dibagi dengan total penjualan.

Variabel dependen dalam penelitian ini adalah pengungkapan aset biologis. Pengungkapan aset biologis pada penelitian ini mengacu kepada PSAK 69 Agrikultur dengan 36 item pengungkapan. Indeks pengungkapan yang digunakan untuk mengukur luas pengungkapan aset biologis diperoleh dengan cara, setiap item yang diungkapkan dalam laporan tahunan akan diberi skor 1 (satu) dan jika tidak diungkapkan diberi skor 0 (nol). Selanjutnya, membandingkan total skor yang diperoleh dari indeks pengungkapan aset biologis dengan total skor yang diwajibkan menurut PSAK 69 Agrikultur.

Tabel 2 Daftar Item Pengungkapan Aset Biologis

\begin{tabular}{ccc}
\hline $\begin{array}{c}\text { Paragraf } \\
\text { PSAK } 69\end{array}$ & Index Pengungkapan & Skor \\
\hline \multicolumn{2}{c}{ Mondatory Item: } \\
& Keuntungan atau kerugian yang timbul selama periode berjalan: & \\
\hline
\end{tabular}




\begin{tabular}{|c|c|c|}
\hline 40 & Pengakuan awal aset biologi & 1 \\
\hline 40 & Pengakuan awal produk agrikultur & 1 \\
\hline 40 & Perubahan nilai wajar dikurangi biaya untuk menjual & 1 \\
\hline 41 & Deskripsi dari setiap kelompok aset biologis & 1 \\
\hline 42 & Penjelasan paragraf 41 & 1 \\
\hline 42 & Penjelasan pengungkapan 41 & 1 \\
\hline \multirow[t]{2}{*}{42} & $\begin{array}{l}\text { Penjelasan aktivitas perusahaan dengan masing-masing kelompok aset } \\
\text { biologis }\end{array}$ & 1 \\
\hline & Penjelasan tahapan pengukuran non keuangan: & \\
\hline 46 & Aset yang ada pada akhir periode & 1 \\
\hline 46 & Hasil agrikultur selama periode tersebut & 1 \\
\hline 46 & $\begin{array}{l}\text { Asumsi dan metode yang digunakan dalam menentukan nilai wajar } \\
\text { masing-masing produk agrikultur pada titik panen dan setiap kelompok } \\
\text { aset biologis }\end{array}$ & 1 \\
\hline 46 & $\begin{array}{l}\text { Nilai wajar dikurangi biaya untuk menjual produk agrikultur yang } \\
\text { dipanen pada periode tersebut }\end{array}$ & 1 \\
\hline 49 & Informasi terkait aset biologis yang dibatasi atau dijaminkan & 1 \\
\hline 49 & Komitmen dalam pembangunan atau akuisisi aset biologis & 1 \\
\hline 49 & Strategi manajemen terkait resiko keuangan aset biologis & 1 \\
\hline 50 & $\begin{array}{l}\text { Penyesuaian terkait perubahan jumlah tercatat aset biologis antara awal } \\
\text { dan akhir periode }\end{array}$ & 1 \\
\hline \multirow[t]{2}{*}{50} & Rekonsiliasi yang meliputi desegregasi & 1 \\
\hline & $\begin{array}{l}\text { Pengungkapan tambahan ketika nilai wajar tidak dapat diukur secara } \\
\text { andal } \\
\text { Entitas mengukur dan mengungkapkan aset biologis berdasarkan biaya } \\
\text { yang mereka tetapkan dikurangi akumulasi penyusutan dan akumulasi } \\
\text { penurunan nilai }\end{array}$ & \\
\hline 54 & Deskripsi aset biologis & 1 \\
\hline 54 & Penjelasan mengapa nilai wajar tidak dapat diukur dengan andal & 1 \\
\hline 54 & Perkiraan tingkat ketidaksesuaian nilai wajar & 1 \\
\hline 54 & Metode penyusutan yang digunakan & 1 \\
\hline 54 & Umur manfaat atau tarif penyusutan yang digunakan & 1 \\
\hline 54 & $\begin{array}{l}\text { Jumlah tercatat bruto dan akumulasi penyusutan (akumulasi rugi } \\
\text { penurunan nilai) pada awal dan akhir periode }\end{array}$ & 1 \\
\hline 55 & Pengakuan keuntungan atau kerugian pelepas aset biologis & 1 \\
\hline 55 & Kerugian penurunan nilai, terkait penghentian aset biologis & 1 \\
\hline 55 & Pembalikan rugi penurunan nilai, terkait penghentian aset biologis & 1 \\
\hline \multirow[t]{2}{*}{55} & Penyusutan, terkait penghentian aset biologis & 1 \\
\hline & $\begin{array}{l}\text { Pengungkapan entitas terkait nilai wajar aset biologis yang } \\
\text { sebelumnya diukur pada biaya yang ditetapkan dikurangi } \\
\text { akumulasi penyusutan dan kerugian penurunan menjadi andal terukur } \\
\text { selama periode berjalan }\end{array}$ & \\
\hline 56 & Deskripsi aset biologis & 1 \\
\hline 56 & Penjelasan mengapa nilai wajar bisa diukur secara andal & 1 \\
\hline \multirow[t]{2}{*}{56} & Pengaruh perubahan tersebut & 1 \\
\hline & Hibah pemerintah & \\
\hline 57 & Pengungkapan entitas terkait hibah pemerintah & 1 \\
\hline
\end{tabular}




\begin{tabular}{|c|c|c|}
\hline 57 & $\begin{array}{l}\text { Sifat dan cangkupan hibah pemerintah yang diakui pada laporan } \\
\text { keuangan keuangan }\end{array}$ & 1 \\
\hline 57 & $\begin{array}{l}\text { Kondisi yang terpenuhi dan kontijensi lainnya yang melekat pada } \\
\text { hibah pemerintah }\end{array}$ & 1 \\
\hline \multirow[t]{3}{*}{57} & Perkiraan penurunan yang signifikan pada jumlah hibah pemerintah & 1 \\
\hline & Non-Mondatory but recommended items: & \\
\hline & $\begin{array}{l}\text { Deskripsi kuantitatif setiap kelompok aset biologis yang } \\
\text { membedakannya dengan: }\end{array}$ & \\
\hline 43 & Aset biologis yang dapat dikomsumsi dan aset produktif & 1 \\
\hline 43 & Aset biologis yang menghasilkan dan belum menghasilkan & 1 \\
\hline \multirow[t]{2}{*}{51} & $\begin{array}{l}\text { Jumlah perubahan nilai wajar dikurangi biaya untuk menjual aset } \\
\text { biologis yang termasuk dalam laba rugi akibat perubahan fisik dan } \\
\text { harga. }\end{array}$ & 1 \\
\hline & Total skor pengungkapan & 36 \\
\hline
\end{tabular}

Sumber: Ikatan Akuntansi Indonesia (2016)

\section{Metode Analisis Data}

Analisis data pada penelitian ini diuji dengan menggunakan program SPSS 22. Model persamaan regresi linear berganda dalam penelitian ini adalah sebagai berikut:

$$
\mathrm{Y}=\mathrm{a}+\beta 1 \mathrm{BAI}+\beta 2 \mathrm{GROWTH}+\beta 3 \mathrm{LVG}+\beta 4 \mathrm{TI}+\mathrm{e}
$$

\section{HASIL DAN PEMBAHASAN Analisis Deskriptif}

Tabel 3

Hasil Statistik Deskriptif

\begin{tabular}{llrrrr}
\hline & $\mathrm{N}$ & \multicolumn{1}{c}{ Minimum } & \multicolumn{1}{c}{ Maximum } & \multicolumn{1}{c}{ Mean } & Std. Deviation \\
\hline PAB & 66 & .0556 & .5556 & .386791 & .1208630 \\
BAI & 66 & .0003 & .6667 & .353388 & .1989061 \\
GROWTH & 66 & -.3062 & .5356 & .048121 & .1469512 \\
LVR & 66 & -10.3144 & 41.2154 & 1.826561 & 5.3996108 \\
TI & 66 & .0000 & .9827 & .159547 & .2315810 \\
Valid N (listwise) & 66 & & & & \\
\hline
\end{tabular}

Sumber: Hasil Olah SPSS 2020

Berdasarkan hasil statistik deskriptif di atas dapat diketahui, bahwa sampel penelitian (N) berjumlah 66 sampel untuk setiap variabel yang diteliti. Variabel Pengungkapan Aset Biologis (PAB) mempunyai nilai terendah sebesar 0,0556, nilai tertinggi sebesar 0,5556, mean sebesar 0,386791 dan standar deviasinya sebesar 0,1208630. Variabel Biological Asset Intensity (BAI) mempunyai nilai terendah sebesar 0,0003 , nilai tertinggi sebesar 0,6667 , mean sebesar 0,353388 dan standar deviasinya sebesar 0,1989061. Variabel Growth (GROWTH) mempunyai nilai terendah sebesar -0,3062, nilai tertinggi sebesar 0,5356, mean sebesar 0,048121 dan standar deviasinya sebesar 0,1469512. Variabel Leverage (LVR) mempunyai nilai terendah sebesar 10.3144, nilai tertinggi sebesar 41,2154, mean sebesar 1.826561 dan standar deviasinya sebesar 5.3996108. Variabel Tingkat Internasional (TI) mempunyai nilai terendah sebesar 0,0000, nilai tertinggi sebesar 0,9827, mean sebesar 0,159547 dan standar deviasinya sebesar 0,2315810. 


\section{Asumsi Klasik Uji Normalitas}

Tabel 4

Hasil Uji Normalitas

\begin{tabular}{llr}
\hline & & Unstandardized Residual \\
\hline $\mathrm{N}$ Normal Parameters & & 66 \\
& &. $\mathrm{~b}$ \\
& Mean & .0000000 \\
& Std. & .09597353 \\
Most Extreme Differences & Deviation & .088 \\
& Absolute & .063 \\
& Positive & -.088 \\
Test Statistic & Negative & .088 \\
Asymp. Sig. (2-tailed) & & .200 \\
\hline
\end{tabular}

a. Test distribution is Normal.

b. Calculated from data.

Sumber: Hasil Olah SPSS 2020.

Berdasarkan hasil uji normalitas di atas diketahui nilai signifikansi (Asymp. Sig. 2-tailed) sebesar 0,200, maka dapat disimpulkan bahwa seluruh variabel dalam penelitian ini memiliki nilai signifikansi $>0,05$ yang artinya data telah terdistribusi dengan normal.

\section{Uji Multikolinearitas}

\section{Tabel 5}

Hasil Uji Multikolinearitas

\begin{tabular}{llcc}
\hline \multicolumn{1}{c}{ Model } & \multicolumn{2}{c}{ Collinearity Statistics } \\
\hline 1 & (Constant) & .831 & VIF \\
& BAI (X1) & .916 & 1.204 \\
GROWTH (X2) & .925 & 1.092 \\
& LVR (X3) & .902 & 1.081 \\
& TI (X4) & & 1.108 \\
\hline
\end{tabular}

a. Dependent Variable: PAB (Y)

Sumber: Hasil Olah SPSS 2020.

Berdasarkan hasil uji multikolinearitas di atas diketahui nilai tolerance untuk variabel Biological Asset Intensity (PAB), Growth (GROWTH), Leverage (LVR) dan Tingkat Internasional (TI) menunjukkan nilai lebih besar dari 0,10. Hasil perhitungan VIF juga menunjukkan hal yang sama yaitu tidak ada satupun variabel independen yang memiliki nilai VIF lebih dari 10. Maka, dapat disimpulkan tidak terjadi multikolinearitas antar variabel independen dalam penelitian ini. 


\section{Uji Heteroskedastisitas}

Tabel 6

Hasil Uji Heteroskedastisitas

\begin{tabular}{|c|c|c|c|c|c|c|}
\hline & \multirow[b]{2}{*}{ Model } & $\begin{array}{l}\text { Unstandardized } \\
\text { Coefficients }\end{array}$ & \multicolumn{2}{|c|}{$\begin{array}{l}\text { Standardized } \\
\text { Coefficients }\end{array}$} & \multirow[b]{2}{*}{$\mathrm{t}$} & \multirow[b]{2}{*}{ Sig. } \\
\hline & & Std. Error & & & & \\
\hline \multirow[t]{5}{*}{1} & (Constant) & .152 & .014 & & 11.101 & .000 \\
\hline & BAI & -.196 & .029 & -.694 & -6.873 & .000 \\
\hline & GROWTH & -.020 & .037 & -.053 & -.554 & .582 \\
\hline & LVR & -.003 & .001 & -.287 & -3.001 & .004 \\
\hline & TI & .008 & .024 & .032 & .326 & .745 \\
\hline
\end{tabular}

a. Dependent Variable: abs_res

Sumber: Hasil Olah Data 2020

Berdasarkan hasil uji heteroskedastisitas di atas menunjukkan variabel Bilogical Asset Intensity (PAB) dan Leverage (LVR) mengalami masalah heterokedastisitas, karena memiliki nilai signifikansi lebih kecil dari 0,05. Agar variabel tersebut terbebas dari masalah heterokedastisitas maka dilakukan transformasi data, yaitu dengan menggunakan transformasi cubic. Transformasi cubic menurut Hidayat (2013) dapat dilakukan dengan cara mengoperasikan pangkat tiga pada nilai asli setiap variabel yang diteliti. Adapun hasil pengujiannya sebagai berikut:

Tabel 7

Hasil Uji Heteroskedastisitas Setelah di Transformasi

\begin{tabular}{|c|c|c|c|c|c|c|}
\hline & \multirow[b]{2}{*}{ Model } & \multicolumn{2}{|c|}{$\begin{array}{l}\text { Unstandardized } \\
\text { Coefficients }\end{array}$} & \multirow{2}{*}{$\begin{array}{l}\text { Standardized } \\
\text { Coefficients } \\
\text { Beta }\end{array}$} & & \multirow[b]{2}{*}{ Sig. } \\
\hline & & B & Std. Error & & & \\
\hline \multirow[t]{5}{*}{1} & (Constant) & .031 & .004 & & 8.317 & .000 \\
\hline & BAI (X1) & -.044 & .0 & -.182 & -1.454 & .151 \\
\hline & GROWTH (X2) & .090 & .108 & .103 & .832 & .409 \\
\hline & LVR (X3) & $-4.297 \mathrm{E}-7$ & .000 & -.187 & -1.503 & .138 \\
\hline & TI (X4) & -.005 & .014 & -.042 & -.336 & .738 \\
\hline
\end{tabular}

a. Dependent Variable: abs_res

Sumber: Hasil Olah Data $20 \overline{20}$

Berdasarkan hasil uji heteroskedastisitas setelah di transformasi di atas menunjukkan nilai signifikansi pada variabel Bilogical Asset Intensity (PAB), Growth (GROWTH), Leverage (LVR) dan Tingkat Internasional (TI) lebih besar dari 0,05 sehingga dapat disimpulkan tidak terjadi masalah heteroskedastisitas.

\section{Uji Autokorelasi}

Tabel 8 Hasil Uji Autokorelasi

\begin{tabular}{rrrrrr}
\hline Model & $\mathrm{R}$ & R Square & $\begin{array}{c}\text { Adjusted R } \\
\text { Square }\end{array}$ & $\begin{array}{c}\text { Std. Error of the } \\
\text { Estimate }\end{array}$ & $\begin{array}{c}\text { Durbin- } \\
\text { Watson }\end{array}$ \\
\hline 1 & $.428^{\mathrm{a}}$ & .183 & .130 & .0346538 & 2.324 \\
\hline
\end{tabular}

a. Predictors: (Constant), TI (X4), LVR (X3), GROWTH (X2), BAI (X1)

b. Dependent Variable: PAB (Y)

Sumber: Hasil Olah SPSS 2020 
Berdasarkan hasil uji autokorelasi di atas menunjukkan nilai Durbin-Watson (DW) ialah sebesar 2,324 dengan nilai $\mathrm{d}_{\mathrm{U}}$ sebesar 1,7319 dan nilai $\mathrm{d}_{\mathrm{L}}$ sebesar 1,4758 sedangkan nilai 4- $\mathrm{d}_{\mathrm{U}}$ sebesar 2,2681 dan nilai 4- $\mathrm{d}_{\mathrm{L}}$ sebesar 2,5242. Maka, Durbin-Watson (DW) terletak antara 4- $\mathrm{d}_{\mathrm{U}}$ dan $4-\mathrm{d}_{\mathrm{L}}$ artinya hasil uji ini tidak menghasilkan keputusan sehingga diperlukan uji run test dalam mengambil keputusan. Adapun hasil dari uji run test tersebut adalah sebagai berikut:

\section{Tabel 9}

\section{Hasil Uji Run Test}

\begin{tabular}{lr}
\hline & Unstandardized Residual \\
\hline Test Value & -.00221 \\
Cases $<$ Test Value & 33 \\
Cases $>=$ Test Value & 33 \\
Total Cases & 66 \\
Number of Runs & 38 \\
$Z$ & .992 \\
Asymp. Sig. (2-tailed) & .321 \\
\hline
\end{tabular}

a. Median

Sumber: Hasil Olah SPSS 2020

Berdasarkan hasil uji run test di atas diketahui bahwa nilai signifikansi (Asymp. Sig. 2-tailed) lebih besar dari tingkat signifikansi 0,05 sehingga dapat disimpulkan tidak terjadi autokorelasi.

\section{Uji Kelayakan Model Uji Koefisiensi Determinasi $\left(R^{2}\right)$}

Tabel 10

Hasil Uji Koefisiensi Determinasi $\left(R^{2}\right)$

\begin{tabular}{|c|c|c|c|c|c|}
\hline Model & $\mathrm{R}$ & R Square & $\begin{array}{l}\text { Adjusted R } \\
\text { Square }\end{array}$ & $\begin{array}{l}\text { Std. Error of the } \\
\text { Estimate }\end{array}$ & Durbin-Watson \\
\hline 1 & $.418^{\mathrm{a}}$ & .183 & .130 & .0346538 & 2.324 \\
\hline
\end{tabular}

a. Predictors: (Constant), TI (X4), LVR (X3), GROWTH (X2), BAI (X1)

b. Dependent Variable: PAB (Y)

Sumber: Hasil Olah SPSS 2020

Berdasarkan hasil uji koefisiensi determinasi di atas menunjukkan bahwa nilai R Square sebesar 0,183 artinya variabel pengungkapan aset biologis dapat dijelaskan oleh variabel biological asset intensity, growth, leverage, dan tingkat internasional sebesar 18,3\%, sedangkan sebesar 81,7\% dipengaruhi oleh variabel lain yang tidak diteliti.

\section{Pengujian Hipotesis Uji Statistik F}

Tabel 11

Hasil Uji Statistik F

\begin{tabular}{llrrrrr}
\hline & Model & Sum of Squares & df & Mean Square & F & Sig. \\
\hline 1 & Regression & .016 & 4 & .004 & 3.419 & $.014^{\mathrm{b}}$ \\
& Residual & .073 & 61 & .001 & & \\
& Total & .090 & 65 & & & \\
\hline
\end{tabular}


a. Dependent Variable: $P A B(Y)$

b. Predictors: (Constant), TI (X4), LVR (X3), GROWTH (X2), BAI (X1)

Sumber: Hasil Olah SPSS 2020

Berdasarkan hasil uji statistik $\mathrm{F}$ di atas menunjukkan bahwa nilai sig $<0,05$, sehingga dapat ditarik kesimpulan bahwa variabel biological asset intensity, growth, leverage, dan tingkat internasional secara simultan berpengaruh terhadap pengungkapan aset biologis.

\section{Uji Statistik t}

Tabel 12

Hasil Uji Statistik t

\begin{tabular}{|c|c|c|c|c|c|c|}
\hline & \multirow[b]{2}{*}{ Model } & \multicolumn{2}{|c|}{$\begin{array}{l}\text { Unstandardized } \\
\text { Coefficients }\end{array}$} & \multirow{2}{*}{$\begin{array}{c}\text { Standardized } \\
\text { Coefficients } \\
\text { Beta }\end{array}$} & \multirow[b]{2}{*}{$\mathrm{t}$} & \multirow[b]{2}{*}{ Sig. } \\
\hline & & B & Std. Error & & & \\
\hline \multirow[t]{5}{*}{1} & (Constant) & .063 & .007 & & 9.643 & .000 \\
\hline & BAI (X1) & .108 & .053 & .237 & 2.016 & .048 \\
\hline & $\begin{array}{l}\text { GROWTH } \\
\text { (X2) }\end{array}$ & .394 & .191 & .240 & 2.064 & .043 \\
\hline & LVR (X3) & $-8.456 \mathrm{E}-7$ & .000 & -.196 & -1.676 & .099 \\
\hline & TI (X4) & -.026 & .025 & -.121 & -1.043 & .301 \\
\hline
\end{tabular}

Sumber: Hasil Olah SPSS 2020

Berdasarkan hasil pengujian statistik $\mathrm{t}$ di atas, maka dapat diuraikan sebagai berikut:

1. Pengujian Hipotesis 1

Variabel biological asset intensity memiliki koefisien regresi (beta) sebesar 0,237 dan nilai sig sebesar 0,048. Tingkat signifikansi variabel biological asset intensity $<0,05$ sehingga dapat disimpulkan bahwa biological asset intensity berpengaruh positif dan signifikan terhadap pengungkapan aset biologis. Dengan demikian maka hipotesis pertama (H1) diterima.

2. Pengujian Hipotesis 2

Variabel growth memiliki koefisien regresi (beta) sebesar 0,240 dan nilai sig sebesar 0,043. Tingkat signifikansi variabel growth $<0,05$ sehingga dapat disimpulkan bahwa growth berpengaruh positif dan signifikan terhadap pengungkapan aset biologis. Maka, hipotesis kedua $(\mathrm{H} 2)$ diterima.

3. Pengujian Hipotesis 3

Variabel leverage memiliki koefisien regresi (beta) sebesar -0,196 dan nilai sig sebesar 0,099. Tingkat signifikansi variabel leverage $>0,05$ sehingga dapat disimpulkan bahwa leverage berpengaruh negatif dan tidak signifikan terhadap pengungkapan aset biologis. Maka, hipotesis ketiga (H3) ditolak.

4. Pengujian Hipotesis 4

Variabel tingkat internasional memiliki koefisien regresi (beta) sebesar -0,121 dan nilai sig sebesar 0,301. Tingkat signifikansi variabel tingkat internasional $>0,05$ sehingga dapat disimpulkan bahwa tingkat internasional berpengaruh negatif dan tidak signifikan terhadap pengungkapan aset biologis. Maka, hipotesis keempat (H4) ditolak. 


\section{PEMBAHASAN}

\section{Pengaruh Biological Asset Intensity Terhadap Pengungkapan Aset Biologis}

Hasil analisis statistik dalam penelitian ini menunjukkan bahwa biological asset intensity berpengaruh positif dan signifikan terhadap pengungkapan aset biologis pada perusahaan agrikultur di Indonesia. Hal tersebut, sesuai dengan teori stakeholder yang dikemukan oleh Ghozali \& Chariri (2007), bahwa perusahaan harus memberikan manfaat kepada stakeholder bukan hanya beroperasi untuk kepentingannya sendiri. Manajemen perusahaan akan berusaha untuk mendapatkan dukungan serta kepercayaan setiap stakeholder-nya, dengan cara menyediakan informasi yang dibutuhkan oleh para stakeholder tersebut (Alfiani, 2019). Adanya informasi mengenai biological asset intensity akan memudahkan stakeholder untuk mengetahui seberapa besar proporsi investasi perusahaan terhadap aset biologis yang dimiliki. Sehingga, perusahaan yang memiliki biological asset intensity yang tinggi akan lebih intensif dalam mengungkapkan aset biologisnya.

Penelitian ini konsisten dengan penelitian yang telah dilakukan oleh Goncalves \& Lopes (2014), Selahudin, et al (2018), Yurniwati, et al (2018), Duwu (2018) dan Putri \& Siregar (2019) bahwa semakin tinggi biological assets intensity perusahaan, maka semakin besar juga dorongan untuk mengungkapkan informasi yang lebih lengkap dan rinci terkait aset biologis yang dimiliki. Hal ini merupakan bentuk pelaporan perusahaan agrikultur atas aset utama yang dimiliki dan dikelola sehingga menjadi sumber laba bagi perusahaan tersebut. Pengungkapan yang secara luas membuat perusahaan agrikultur mudah menarik investor dan meyakinkan kreditor untuk meningkatkan pendanaan mereka. Hasil penelitian ini bertolak belakang dengan penelitian Pramitasari (2018) dan Sa'diyah, et al (2019) bahwa biological asset intensity berpengaruh negatif terhadap pengungkapan aset biologis.

\section{Pengaruh Growth Terhadap Pengungkapan Aset Biologis}

Hasil analisis statistik dalam penelitian ini menunjukkan bahwa growth berpengaruh positif dan signifikan terhadap pengungkapan aset biologis pada perusahaan agrikultur di Indonesia. Hasil tersebut sesuai dengan teori stakeholder yang dikemukan oleh Deegan (2004), bahwa semua stakeholder berhak untuk mengetahui setiap informasi dari kegiatan organisasi yang dapat mempengaruhi kedudukan mereka. Informasi mengenai aset biologis akan berguna bagi stakeholder untuk mengetahui nilai aset biologis yang wajar sesuai dengan kontribusinya dalam menghasilkan aliran kas bagi perusahaan. Sehingga, pengungkapan aset biologis meningkat seiring dengan pertumbuhan yang terjadi pada perusahaan.

Hasil penelitian ini sejalan dengan penelitian yang telah dilakukan oleh Alfiani (2019) bahwa growth memiliki pengaruh positif terhadap pengungkapan aset biologis. Perusahaan yang memiliki tingkat pertumbuhan tinggi akan cenderung lebih banyak mendapatkan sorotan, sehingga perusahaan tersebut akan melakukan pengungkapan yang lebih luas mengenai informasi keuangan maupun non keuangan yang mereka miliki. Maka, pertumbuhan perusahaan meningkat sejalan dengan peningkatan pengungkapan yang dilakukan mengenai aset biologis yang dimilikinya. Hasil penelitian ini bertolak belakang dengan penelitian Lopes \& Goncalves (2015) dan Selahudin, et al (2018) bahwa growth berpengaruh negatif terhadap pengungkapan aset biologis.

\section{Pengaruh Leverage Terhadap Pengungkapan Aset Biologis}

Hasil analisis statistik dalam penelitian ini menunjukkan bahwa leverage berpengaruh negatif dan tidak signifikan terhadap pengungkapan aset biologis pada perusahaan agrikultur di 
Indonesia. Semakin tinggi tingkat leverage yang dimiliki oleh perusahaan maka semakin rendah pula tingkat pengungkapan aset biologis yang dilakukannya. Hal tersebut berkaitan dengan teori signaling, dimana setiap informasi yang dikeluarkan oleh perusahaan dapat merubah penilaian investor ataupun kreditor terhadap perusahaan (Gumanti, 2009). Sehingga manajemen perusahaan akan lebih hati-hati dalam memilah informasi yang akan diungkapkannya secara rinci dalam laporan tahunan (annual report).

Penelitian ini konsisten dengan penelitian yang telah dilakukan oleh Lopes \& Goncalves (2015) dan Sari (2019) bahwa perusahaan agrikultur dengan leverage yang tinggi akan melakukan pengungkapan yang lebih sedikit jika dibandingkan perusahaan agrikultur dengan leverage yang rendah. Hal tersebut berkaitan dengan respon yang akan diberikan kreditor kepada perusahaan. Pengungkapan aset biologis secara luas membuat kreditor akan beranggapan bahwa banyaknya aset biologis yang dimiliki oleh perusahaan dibiayai oleh hutang, sehingga menjadi sinyal negatif bagi kreditor. Hasil penelitian ini bertolak belakang dengan penelitian Selahudin, et al (2018) dan Pramitasari (2018) bahwa leverage berpengaruh postif terhadap pengungkapan aset biologis.

\section{Pengaruh Tingkat Internasional Terhadap Pengungkapan Aset Biologis}

Hasil analisis statistik dalam penelitian ini menunjukkan bahwa tingkat internasional berpengaruh negatif dan tidak signifikan terhadap pengungkapan aset biologis pada perusahaan agrikultur di Indonesia. Hal tersebut sesuai dengan pernyataan Sa'diyah, et al (2019) bahwa perusahaan dengan tingkat internasionalisasinya yang rendah cenderung melakukan pengungkapan aset biologis lebih lengkap, jika dibandingkan pada perusahaan agrikultur yang mempunyai tingkat internasional yang tinggi. Hal ini dikarenakan standar akuntansi terkait pengungkapan aset biologis baru berlaku efektif di Indonesia pada bulan Januari 2018. Sehingga, dari tahun 2015 hingga 2017 perusahaan yang memiliki tingkat internasionalisasi tinggi masih membatasi pengungkapan aset biologis mereka.

Penelitian ini konsisten dengan hasil penelitian yang telah dilakukan oleh Lopes \& Goncalves (2015) bahwa tingkat internasionalisasi memiliki pengaruh negatif namun tidak signifikan terhadap pengungkapan aset biologis. Semakin tinggi tingkat internasional yang dimiliki oleh perusahaan agrikultur maka semakin rendah pengungkapan mengenai aset biologis dalam laporan tahunan (annual report). Walaupun demikian, informasi mengenai aset biologis tersebut tidak terlalu menjadi pusat perhatian bagi investor dalam berinvestasi. Sehingga tingkat internasional tidak berpengaruh signifikan terhadap tingkat pengungkapan aset biologis pada perusahaan agrikultur. Hasil penelitian ini bertolak belakang dengan penelitian Souza \& Almeida (2017) dan Pramitasari (2018) bahwa tingkat internasional berpengaruh postif terhadap pengungkapan aset biologis.

\section{SIMPULAN, KETERBATASAN DAN SARAN \\ Simpulan}

Berdasarkan hasil analisis data pengaruh biological asset intensity, growth, leverage dan tingkat internasional terhadap pengungkapan aset biologis pada perusahaan agrikutur yang terdaftar di Bursa Efek Indonesia (BEI) tahun 2015-2018, maka dapat disimpulkan sebagai berikut:

1. Biological asset intensity berpengaruh positif dan signifikan terhadap pengungkapan aset biologis pada perusahaan agrikultur yang terdaftar di Bursa Efek Indonesia (BEI) tahun 20152018.

2. Growth berpengaruh positif dan signifikan terhadap pengungkapan aset biologis pada 
perusahaan agrikultur yang terdaftar di Bursa Efek Indonesia (BEI) tahun 2015-2018.

3. Leverage berpengaruh negatif dan tidak signifikan terhadap pengungkapan aset biologis pada perusahaan agrikultur yang terdaftar di Bursa Efek Indonesia (BEI) tahun 2015-2018.

4. Tingkat Internasional berpengaruh negatif dan tidak signifikan terhadap pengungkapan aset biologis pada perusahaan agrikultur yang terdaftar di Bursa Efek Indonesia (BEI) tahun 20152018.

\section{Keterbatasan}

Penelitian ini memiliki keterbatasan yang dapat dijadikan acuan bagi penelitian selanjutnya agar memperoleh hasil yang lebih baik. Keterbatasan dalam penelitian ini adalah sebagai berikut:

1. Pada penelitian ini hanya terdapat 66 perusahaan agrikultur yang memenuhi kriteria selama tahun penelitian 2015-2018 secara tidak berurutan, sehingga kurang menggambarkan kekonsistenan pengungkapan aset biologis perusahaan agrikultur.

2. Pada penelitian ini hanya memiliki nilai R Square sebesar 18,3\%. Hal tersebut menunjukkan bahwa terdapat variabel lain yang tidak digunakan dalam penelitian ini yang memiliki pengaruh besar terhadap pengungkapan aset biologis.

3. Pada penelitian ini hanya menggunakan tahun penelitian 2015-2018. Hal tersebut disebabkan laporan keuangan dan laporan tahunan yang telah di audit untuk tahun 2019 masih banyak perusahaan yang belum menerbitkan hingga data dalam penelitian ini selesai diolah.

\section{Saran}

Berdasarkan kesimpulan dan keterbatasan penelitian di atas maka dapat diberikan saran sebagai berikut:

1. Bagi perusahaan agrikultur dalam mengungkapkan aset biologisnya haruslah lebih rinci dan lengkap terkait aktivitas agrikultur yang dilakukan perusahaan, sehingga menjadi nilai tambah di mata pengguna laporan keuangan.

2. Bagi peneliti selanjutnya disarankan untuk menambah variabel lain yang mungkin berpengaruh terhadap pengungkapan aset biologis seperti company size, type firm dan ownership concentration.

3. Bagi peneliti selanjutnya disarankan untuk menggunakan tahun terbaru dan memperpanjang periode penelitian, sehingga dapat menggambarkan kondisi pengungkapan aset biologis terkini.

\section{DAFTAR PUSTAKA}

Alfiani, L. K. (2019). Pengaruh Biological Asset Intensity, ukuran Perusahaan, pertumbuhan Perusahaan, Konsentrasi Kepemilikan Manajerial, Dan Jenis KAP Terhadap Pengungkapan Aset Biologis. Universitas Muhammadiyah Yogyakarta.

Amelia, D. (2016). Pengaruh Profitabilitas Leverage, Pertumbuhan Perusahaan, Tipe Industri, dan Kepemilikan Saham, Publik Terhadap Corporate Responsibilty. Universitas Esa Unggul.

Amelia, F. (2017). Pengaruh Biological Asset Intensity, Ukuran Perusahaan, Konsentrasi Kepemilikan dan Jenis KAP Terhadap Pengungkapan Aset Biologis. Universitas Unand.

Astuti, R. P. (2015). Pengaruh Profitabilitas, Ukuran Perusahaan, dan Mekanisme Corporate Governance Terhadap Pengungkapan Sukarela. Universitas Muhammadiyah Purwokerto.

Brigham, \& Houston. (2013). Dasar-Dasar Manajemen Keuangan Buku 1 (11 ed.). Selemba Empat. 
Daniel, S. J., Jung, B., Pourjalali, H., \& Wen, E. (2010). Firm Characteristics Influencing Responses towards the Adoption of Fair Value Accounting for Non-financial Assets : A Survey of Chief Financial Officers of U . S . Firms. SS, 1-34.

Daske, H., Hail, L., Leuz, C., \& Verdi, R. (2013). Adopting a Label: Heterogeneity in the Economic Consequences Araund IAS/IFRS Adoption. Journal Accounting Research, 51(3).

Deegan, C. (2004). Financial Accounting Theory. McGraw-Hill Book Company.

Diphayana, W. (2014). Bisnis Internasional BAB I: Kerakteristik Bisnis Internasional. Internasional. http://wahonodiphayana.blogspot.com

Duwu, M. I. (2018). Pengaruh Biological Asset Intensity, Ukuran Perusahaan, konsentrasi Kepemilikan, Jenis KAP, Dan Profitabilitas Terhadap Biological Asset Disclosure. Jurnal Akuntansi \& Keuangan Daerah, 13(November), 56-75.

Ghozali, I., \& Chariri. (2007). Teori Akuntansi. Universitas Diponegoro.

Goncalves, R., \& Lopes, P. (2014). Firm-specific determinants of agricultural financial reporting. Procedia - Social and Behavioral Sciences, 110, 470-481.

Gumanti, T. A. (2009). Teori Sinyal Dalam Manajemen Keuangan. Researchgate.

Harahap, S. S. (2013). Analitis Kritis atas Laporan Keuangan. Rajawali Pers.

Hidayat, A. (2013). Pengertian dan Jenis Transformasi Data. Statistikian.com. http;//www.google.com/amp/s/www.statitikian.com/2013/01/transformasi-data.html

Ikatan Akuntansi Indonesia. (2016). PSAK 69 Agrikultur. Ikatan Akuntansi Indonesia.

Jensen, M., \& Meckling, W. (1976). Theory of the Firm: Managerial Behavior, Agency Costs, and Ownership Structure. Journal of Financial Economics, 3(4), 305-360.

Kamijaya, M. (2019). Pengaruh Ukuran Perusahaan, Konsentrasi Kepemilikan, Dan Profitabilitas Terhadap Pengungkapan Aset Biologis. Universitas Katolik Widya Mandala.

Khanna, T., Palepu, K., \& Srinivasan, S. (2004). Disclosure Practices of Foreign Companies Interacting with U.S Markets. Journal Accounting Research, 42(2).

Kusumadewi, A. A. (2018). Pengaruh Biological Asset Intensity dan Ukuran Perusahaan Terhadap Pengungkapan Aset Biologis. Universitas Pasundan.

Lestari, P. (2016). Faktor-Faktor yang Mempengaruhi Tingkat Pengungkapan Internet Financial Reporting. Universitas Muhammadiyah Yogyakarta.

Lopes, R. D. das N., \& Goncalves, S. (2015). Accounting for Biological Assets: Discloure, Measurement, and Value Relevence. University Porto.

Machdar, N. M. (2014). Pengaruh Karakteristik Perusahaan Terhadap Pengungkapan Pelaporan Serta Implikasinya Terhadap Kualitas Laba. Media Riset Akuntansi, Auditing \& Informasi, 14(1), 61-88.

Munsaidah, S., Andini, R., \& Supriyanto, A. (2016). Analisis Pengaruh Firm Size, Age, Profitabilitas, Leverage, dan Growth Perusahaan Terhadap Corporate Social Responsibility (CSR). Journal Of Accounting, 2(2).

Pramitasari, R. K. D. (2018). Pengaruh Faktor Firm Level Terhadap Pengungkapan Aset Biologis Pada Perusahaan Perkebunan Terdaftar di BEI Tahun 2012-2016. Universitas Airlangga.

Purnasiwi, J. (2011). Analisis Pengaruh Size, Profitabilitas dan Leverage Terhadap Pengungkapan CSR .Universitas Diponegoro.

Putri, M. O., \& Siregar, N. Y. (2019). Pengaruh Biological Asset Intensity, Ukuran Perusahaan, Kepemilikan Manajerial, Dan Jenis KAP Terhadap Pengungkapan Aset Biologis. Jurnal Akuntansi \& Keuangan, 10(2), 44-70.

Putri, R. K. (2017). Pengaruh Ukuran Perusahaan, Profitabilitas, Leverage, Likuiditas, dan Basis 
Kepemilikan Terhadap Corporate Social Responsibility. JOM Fekon, 4(1), 558-571.

Sa'diyah, L. D. J., Dimyati, M., \& Murniati, W. (2019). Pengaruh Biological Asset Intensity , Ukuran Perusahaan, dan Tingkat Internasionalisasi Terhadap Pengungkapan Aset Biologis. Progress Conference, 2(July), 291-304.

Sari, I. M. (2019). Pengaruh Biological Asset Intensity, Ukuran Perusahaan, Konsentrasi Kepemilikan, Jenis KAP, Profitabilitas dan Leverage terhadap Pengungkapan Aset Biologis .Universitas Bina Darma.

Selahudin, N. F., Firdaus, F. N. M., Sukri, N. S. A. M., Gunasegran, S. N., \& Rahim, S. F. A. (2018). Biological Assets: The Determinants of Disclosure. Global Business and Management Research: An International Journal, 10(3), 170-178.

Sinurat, D. N. B., \& Sembiring, E. R. (2016). Pengaruh Profitabilitas, Leverage, Struktur Kepemilikan Dan Status Perusahaan Terhadap Pengungkapan Laporan Keuangan Pada Perusahan Manufaktur Yang Terdaftar Di Bursa Efek Indonesia. Jurnal Riset Akuntanso dan Keuangan, 2(1), 63-82.

Souza, P. V. S. de M., \& Almeida, S. R. V. (2017). Fatores Relacionados Ao Nível De Disclosure Das Companhias Brasileiras De Capital Aberto Listadas Na Bm\&Fbovespa1 Factors Related To The Brazilian Companies' Disclosure Level With Open Capital Listed On The Bm\&Fbovespa Factores Relacionados A La Divulgaci. Revista Universo Contábil, 13(2), 166-186.

Suwardjono. (2014). Teori Akuntansi Perekayasaan Pelaporan Keuangan (Edisi Ketiga). BPFE. Yamaditya, V., \& Raharja. (2014). Pengaruh Asimetri Informasi, Leverage, dan Ukuran Perusahaan Terhadap Praktik Manajemen Laba. Diponegoro Journal of Accounting, 3(4), $1-12$.

Yurniwati, Amsal, D., \& Amelia, F. (2018). Effect of Biological Asset Intensity , Company Size , Ownership Concentration, and Type Firm against Biological Assets Disclosure. The Indonesian Journal of Accounting Research, 21(1), 121-146. 